\title{
Pendampingan Pemetaan Potensi Ekowisata bagi Masyarakat Desa Banjarasri, Kalibawang, Kulon Progo
}

\author{
Yohanes Satyayoga Raniasta $^{\# 1}$, Adimas Kristiadi ${ }^{\# 2}$ \\ \#Program Studi Arsitektur, Fakultas Arsitektur dan Desain, \\ Universitas Kristen Duta Wacana Yogyakarta \\ ${ }^{1}$ satyayogalstaff.ukdw.ac.id \\ 2adimas.kristiadiestaff.ukdw.ac.id
}

\begin{abstract}
Abstrak - Desa Banjarasri, Kalibawang, Kulon Progo merupakan salah satu desa yang memiliki potensi wisata yang mumpuni untuk dikembangkan menjadi desa dengan konsep wisata yang menarik aktivitas wisata daerah maupun nasional. Potensi wisata dengan tema ekowisata dan budaya sangat sesuai untuk dikembangkan di Desa Banjarsari bila melihat pada karakteristik tipologi dan geografinya. Namun potensi tersebut masih belum dikembangkan dan dikemas dengan baik sebagai destinasi objek wisata. Untuk itu kegiatan pengabdian masyarakat yang dilakukan oleh Universitas Kristen Duta Wacana bertujuan untuk membantu menggali dan menemukan konsep wisata yang ada serta bersama-sama dengan masyarakat dan pihak pemerintah setempat untuk merumuskan konsep ekowisata yang lebih tepat yakni dengan menggunakan 5 (lima) karakteristik dasar ekowisata antara lain: 1) nature based; 2) ecologically sustainable; 3) environmentally educative; 4) locally beneficial; dan 5) generate visitor. Metode kegiatan pengabdian ini adalah melalui Focus Group Discussion, Workshop Partisipatif, serta Survey Lapangan titik-titik potensial bersama masyarakat setempat dalam menggali dan menemukan potensi wisata Desa Banjarasri, yang hasilnya digunakan dalam membuat peta induk pengembangan kawasan wisata desa, serta usulan rancangan amenitas pendukungnya.
\end{abstract}

Kata kunci-ekowisata, pemetaan, partisipasif, Desa Banjarasri

Abstract-Banjarasri Village, Kalibawang, Kulon Progo has tourism potential to be developed into a village with a tourism concept that attracts local, regional, and national tourism activities. Tourism potential with the theme of ecotourism and culture is very suitable for developing in Banjarsari Village when looking at the typological and geographical characteristics. However, this potential has not yet been developed and packaged properly as a tourist destination. For this reason, community service activities carried out by the Duta Wacana Christian University aim to help explore and find existing tourism concepts and together with the community and local government to formulate a more appropriate ecotourism concept by using 5 (five) basic characteristics of ecotourism, including 1) naturebased; 2) ecologically sustainable; 3) environmentally educative;
4) locally beneficial, and 5) generate visitors. The method of this service activity is through Focus Group Discussions, Participatory Workshops, as well as Field Surveys of potential points with the local community in exploring and discovering the tourism potential of Banjarasri Village, and the results are used to make a Village Tourism Map, as well as proposed supported amenities designs.

Keywords - eco-tourism, mapping, participatory, Banjarasri Village

\section{Pendahuluan}

Kegiatan wisata adalah salah satu generator penggerak ekonomi yang memiliki dampak signifikan untuk suatu wilayah. Dalam kurun waktu beberapa tahun kebelakang, slogan ekowisata pada desa wisata menjadi tren di kalangan masyarakat. Kegiatan rekreasi berbasis alam yang menekankan pembelajaran kelestarian lingkungan menjadi daya tarik utama dalam pengembangan ekowisata. Tren yang sedang berkembang atas kegiatan pariwisata minat khusus dengan bentuk pembelajaran lingkungan tersebut merupakan bentuk perubahan kesadaran masyarakat bahwa pariwisata yang bersifat mass tourism tidak dapat memberikan pengalaman dan kesan yang diharapkan saat ini [1]. Masyarakat membutuhkan waktu dan tempat untuk sejenak kembali ke alam dalam menikmati kehidupan.

Ekowisata tidak dapat dipisahkan dari konsep berkelanjutan. Konsep pariwisata yang berkelanjutan sudah menjadi kewajiban dan melekat dalam proses pembangunan, pengelolaan dan pengembangan ekowisata. Pada dasarnya pariwisata yang berkelanjutan berfokus pada bagaimana seluruh elemen kegiatan wisata yang dikembangkan tidak mengganggu ekosistem dengan pemberdayaan masyarakat setempat sehingga mengalami peningkatan kualitas hidup dan dapat diwariskan untuk generasi mendatang [2] dan [3].

Desa Banjarasri, Kalibawang, Kulon Progo merupakan salah satu destinasi ekowisata yang masuk ke dalam 15 
besar desa wisata terbaik mewakili Kulon Progo untuk masuk ke tingkat nasional sejak September 2012 [4]. Kegiatan yang ditawarkan yaitu rekreasi bernuansa alam yang jauh dari kebisingan dan hiruk pikuk perkotaan. Atmosfer pedesaan yang asri secara kental disajikan dari kolaborasi topografi alam yang indah. Kegiatan alam seharihari di kawasan pedesaan dilakukan diselingi dengan relasi yang ramah bersama warga sekitar. Namun saat ini potensi yang ada tersebut belum dikembangkan dengan maksimal. Untuk itu kegiatan pengabdian masyarakat yang dilakukan oleh tim pengabdian Program Studi Arsitektur dan Desain, Universitas Kristen Duta Wacana membantu menggali dan menemukan tema konsep ekowisata yang ada bersama dengan masyarakat dan pemerintah setempat dengan memfokuskan pada 5 (lima) karakteristik dasar ekowisata yang berkelanjutan [5] dan [6] yaitu: 1) nature based, secara maksimal mengolah potensi sumber daya alam ataupun keanekaragaman hayati beserta ekosistemnya sebagai nilai jual; 2) ecologically sustainable, secara maksimal mendukung ekologi yang berkelanjutan, bagaimana pembangunan yang ada nantinya tidak mengganggu dan merusak fungsi ekologis atau memberikan dampak negatif bagi ekologi setempat; 3) environmentally educative, secara maksimal mempengaruhi masyarakat dan wisatawan untuk peduli terhadap konservasi. Selain itu prinsip socially and culturally accept yaitu adanya penerimaan secara social dan budaya yang mengacu pada kemampuan masyarakat lokal untuk terbuka menyerap aktivitas pariwisata yang kompleks tanpa konflik sosial juga diperlukan; 4) locally beneficial, secara maksimal melibatkan masyarakat dalam kegiatan ekowisata sehingga mendapatkan keuntungan baik secara langsung maupun tidak langsung. Adapun dengan prinsip economically viable bahwa keuntungan ekonomi dari kegiatan wisata haruslah meningkatkan kesejahteraan masyarakat lokal setempat; 5) generate visitor satisfaction, secara maksimal menyediakan kepuasan hingga meningkatkan kesadaran dan penghargaan wisatawan terhadap konservasi alam. Dengan prinsip technologically appropriate kepuasan dapat dicapai dengan adanya penerapan teknologi yang tepat dan dapat mendukung kegiatan pariwisata di wilayah setempat.

Proses partisipatif dilakukan dalam pengembangan konsep ekowisata Desa Banjarasri dengan melibatkan masyarakat seara aktif dalam survey dan diskusi, Dengan landasan ekowisata yang berkelanjutan maka ditiap pengambilan keputusannya harus melalui proses musyawarah untuk mufakat yang mana masyarakat memiliki peran aktif dan tanggung jawab [7].

Target dari kegiatan pengabdian kepada masyarakat ini yaitu pemberdayaan masyarakat yang mana dalam proses pemetaan potensi wisata selalu melibatkan masyarakat sebagai pihak yang memiliki pengetahuan empiris tentang keadaan dan kenyataan kondisi eksisting di lapangan. Tim pengabdian dan masyarakat melakukan kegiatan kolaboratif yang mana tim pengabdian sebagai akademisi dengan pemahaman teoritis dan praktis memberi pendampingan kepada masyarakat. Adapun luaran kegiatan pengabdian kepada masyarakat ini nantinya berupa dokumen pendukung dalam pengembangan kawasan wisata Desa Banjarasri yang berisikan informasi grafis dalam bentuk deskriptif yang dapat membantu masyarakat dan pemerintah setempat untuk tegas menentukan arah yang tepat dalam pengembangan ekowisata di Desa Banjarasri, Kalibawang, Kulon Progo. Dokumen pendukung tersebut berupa:

1. Desain Poster Peta Besar Ekowisata Desa Banjarasri

Berisi tentang informasi klasifikasi tempat wisata hasil survey dan masukan-masukan dari warga setempat. Informasi tersebut menjelaskan tentang obyek-obyek tujuab wisata: something to see and something to do in Banjarasri.

2. Desain Pamflet

Berisi informasi titik-titik wisata pengembangan dari desain poster ekowisata Desa Banjarasri yang disajikan dalam pamflet yang siap cetak dengan ukuran yang mudah dibawa oleh wisatawan.

3. Usulan Rancangan Amenitas Pendukung

Berisi gagasan dasar rancangan amenitas pendukung yang dapat meningkatkan performa konsep ekowisata Desa Banjarasri.

\section{Metode PelaKsanaAN}

Metode pelaksanaan kegiatan pengabdian kepada masyarakat ini dilakukan dengan metode partisipatori yang mana pada pelaksanaannya masyarakat Desa Banjarasri-lah yang menjadi subyek dan pelaku utama dari kegiatan pemetaan potensi wisata tersebut. Dalam metode partisipatori ini berbagai elemen masyarakat yang dilibatkan secara sukarela [8] meliputi pemerintah desa setempat (PJ lurah dan staf, kepala dusun, ketua RT dan RW, perkumpulan pemuda Karang Taruna, pelaku usaha kecil, serta tokoh masyarakat yang memiliki peran penting). Dengan proses partisipatif, diharapkan akan memperoleh banyak manfaat antara lain:

1. Masyarakat akan merasa memiliki dengan peran dan kontribusi mereka yang besar, sehingga ke depannya akan secara mandiri dapat mengembangkan embrio ekowisata yang saat ini akan dimulai melalui pemetaan awal.

2. Memudahkan pendataan untuk pemetaan awal. Masyarakat desa setempatlah yang paling mengetahui kondisi dan potensi-potensi yang ada di lokasi. Sehingga berbagai informasi yang didapatkan dari mereka (baik tangible maupun intangible) akan lebih lengkap. 
Pada praktiknya kegiatan pengabdian yang dilakukan ini berupa rangkaian penyuluhan dan pelatihan (sharing dan workshop) serta diskusi yang bersifat brainstorming. Penyuluhan diberikan untuk memberikan gambaran awal tentang pengetahuan dasar tentang pengelolaan potensi ekowisata desa. Selanjutnya diskusi dan workshop bertujuan untuk menggali informasi dari masyarakat tentang apa dan bagaimana kondisi spot desa yang berpotensi untuk dikembangkan menjadi ekosiwisata yang terintegrasi.

Peran atau dukungan dari mitra (masyarakat Desa Banjarasri) sebagai peserta adalah memberikan konstribusi aktif tentang pemikiran dan pengetahuannya tentang Desa Banjarasri serta menyiapkan tempat untuk berdiskusi secara efektif dengan merespon kondisi akatual saat ini tentang protokol kesehatan covid-19.

\section{PEMBAHASAN}

Proses pendampingan masyarakat Desa Banjarasri pada pengabdian ini dilakukan melalui 4 (empat) tahapan utama yaitu Konsolidasi, Identifikasi, Analisis dan Konsepsi, serta Sosialisasi.

1. Tahap Konsolidasi : tahap ini merupakan awal dari proses pendampingan, dimana dilakukan pertemuan dengan Kepala Desa, serta tokoh-tokoh masyarakat setempat, yang dilanjutkan dengan penandatanganan form kesepakatan bekerja sama. Penyamaan visi misi, tujuan, sasaran bersama ke depan adalah hal yang sangat penting. Setiap pihak harus menjadi bagian penting dan mengambil peran aktif pada setiap prosesnya, karena tujuan dari pengabdian ini adalah membangun kemandirian warga untuk mengembangkan desa melalui pariwisata. Edukasi akan eko-wisata dengan 5 (lima) karakteristiknya diberikan dari tim pengabdian kepada masyarakat sebagai framing awal.

2. Tahap Identifikasi : pada tahap ini dilakukan pengumpulan data, baik primer maupun sekunder sebagai bahan untuk tahap selanjutnya. Untuk mendapatkan data sekunder dilakukan dengan pencarian data terkait wisata-wisata yang telah atau pernah berjalan di Desa Banjarasri dari web pemerintah setempat, studi-studi akademik, ataupun info-info ringan yang populer dari media sosial. Data berupa peta didapatkan dari google earth, sedangkan spot wisata populer didapatkan dari website wisata yang mengulas tentang destinasi wisata populer. Untuk mendapatkan data primer, maka tim bersama dengan warga masyarakat setempat yang menjadi dampingan, melakukan survei dan diskusi grup terfokus (FGD). Berdasarkan diskusi awal dan data-data sekunder, dibuat peta awal titik-titik lokasi wisata yang akan disurvey. Selanjutnya bersama dengan warga setempat, dilakukan kunjungan lapangan ke titik-titik tersebut. Selama melakukan survei, Bapak Supardi, bersama Bapak Adit, Mas Yogi, dan Mas Yuli adalah beberapa tokoh masyarakat setempat yang turut ke lapangan, dimana mereka banyak bercerita tentang sejarah lokasi, perkembangannya, sampai berbagai kendala yang dihadapi. Mereka juga menyampaikan harapan-harapan untuk desanya, dimana dapat diterjemahkan sebagai harapan untuk pembangunan desa melalui sektor pariwisata.

Pada gambar di bawah ini adalah sebagian dokumentasi dari kegiatan survey yang dilakukan yaitu di Puncak Kuda Sembrani dan di Gua Maria Watu Blencong. Berdasarkan harapan dari warga, kedua spot ini memiliki tingkat urgensi yang lebih tinggi dibandingkan spot wisata yang lain, sehingga menjadi prioritas awal untuk rencana pengembangan. Puncak Kuda Sembrani adalah sebuah titik atas dari bagian Perbukitan Menoreh yang berada di ketinggian sekitar $300 \mathrm{dpl}$, yang dapat ditempuh dengan berjalan kaki dari titik awal di kaki bukit dengan durasi sekitar 60 menit. Sedangkan Gua Maria Watu Blencong adalah sebuah tempat peziarahan yang masih berupa embrio dan belum mendapat sentuhan untuk pengembangan secara lebih layak. Boro, Banjarasri dikenal sebagai desa misionaris masa-masa awal dimana pada masa penjajahan Belanda, terdapat beberapa misionaris yang berasal dari Eropa, mendirikan gereja, rumah sakit, panti asuhan, serta pertenunan untuk dapat masuk ke masyarakat di wilayah Yogyakarta dan Jawa Tengah pada khususnya, dan Pulau Jawa pada umumnya.

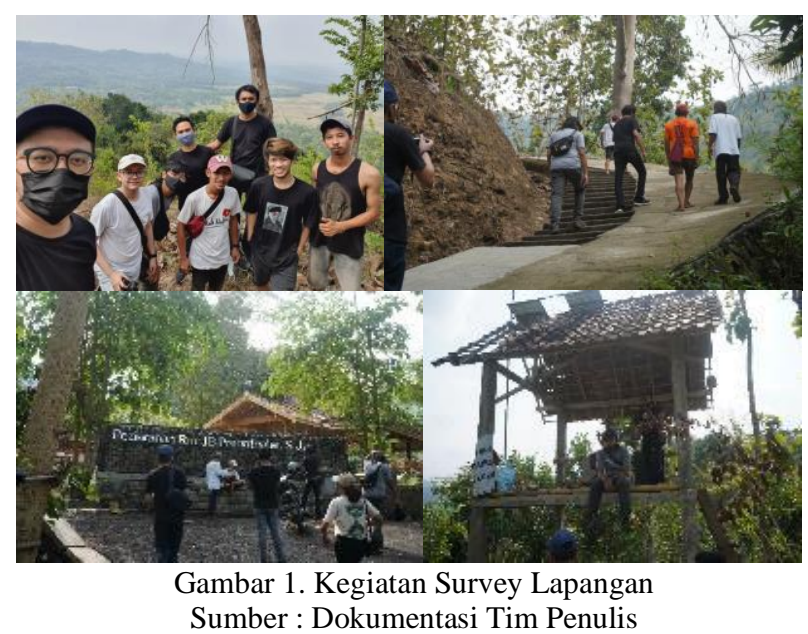

3. Tahap Analisis dan Konsepsi : tahap ini dilakukan sebagai tindak lanjut dari tahap identifikasi, dimana dalam melakukan analisis dan penyusunan konsep, digunakan metode partisipatori dengan melibatkan masyarakat yang menjadi dari subyek pendampingan. 
Proses focus group discussion (FGD) atau diskusi grup terfokus dilakukan di salah satu spot wisata kuliner di Desa Banjarasri, dan dengan protokol kesehatan yang ketat. FGD diawali dengan paparan singkat oleh tim pengabdian tentang kompilasi data baik data primer dari hasil survei lapangan bersama, maupun data sekunder dari website dan media sosial. Dipaparkan kembali juga tentang 5 (lima) prinsip pengembangan eko-wisata desa yaitu : nature-based, ecologically-sustainable, environmentally educative, locally beneficial, serta generate visitor satisfaction. Prinsip ini disampaikan agar senantiasa diterapkan selalu untuk setiap proses pengembangan wisata selanjutnya, agar konsep dari ecowisata Boro Banjarasri dapat terwujud.

Setelah paparan tim, dilakukan workshop dimana warga masyarakat menjadi peserta aktif sedangkan tim pengabdian menjadi fasilitator. Menggunakan media peta buta berukuran besar, warga dibagi menjadi 3 grup, lalu setiap grup dipandu untuk melakukan diskusi tentang potensi-potensi wisata desa yang sudah ada atau yang menjadi harapan ke depan untuk dikembangkan, yang kemudian hasil diskusi tersebut mereka tuangkan dengan coretan gambar dan tulisan di atas peta yang telah disediakan. Diskusi ini berjalan dengan hangat, dimana muncul berbagai informasi serta ide yang baru.

Selanjutnya dilakukan presentasi dari masingmasing tim untuk memaparkan hasil diskusi. Media presentasi adalah peta titik potensi wisata desa yang mereka paparkan secara merinci terkait apa, mengapa, dan bagaimana spot wisata tersebut ada dan potensial untuk dikembangkan. Presentasi ini seluruhnya dilakukan dengan kerjasama setiap anggota, dengan ketua tim memaparkan overview hasil mapping (peta hasil coret-coretan difoto dan ditayangkan menggunakan laptop dan viewer), dibantu anggota timnya yang secara bergantian membantu menjelaskan setiap spot wisata yang ada dalam peta.

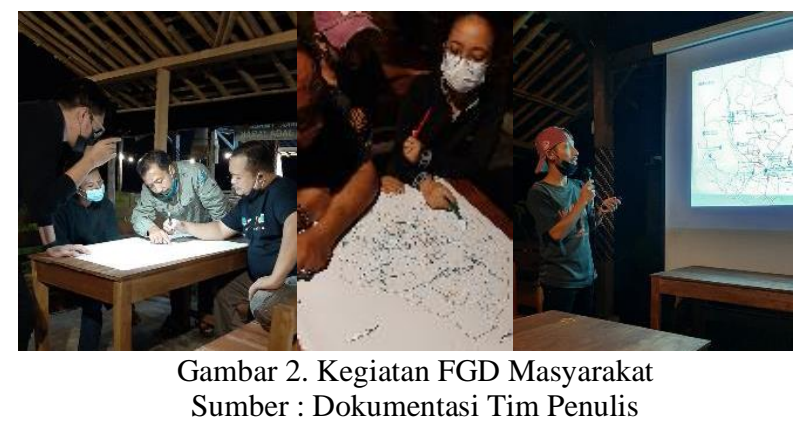

Hasil diskusi ini kemudian dirangkum oleh tim untuk memperkaya data dan informasi yang telah ada sebelumnya dan merepresentasikan keinginan yang besar dari warga untuk membangun desanya. Penyajian dari konsep ini tertuang dalam sebuah peta besar potensi wisata Boro, Banjarasri. Spot-spot ini dikategorikan menjadi beberapa tema yaitu : Wisata Sejarah-Religi, Wisata Alam, Wisata Minat Khusus, Wisata Kuliner Umum, dan Wisata Kuliner Khusus (segmen khusus non halal : B2). Tujuan dari kategorisasi ini adalah untuk memudahkan masyarakat ataupun wisatawan yang datang agar dapat memilah dan memilih tempat yang menjadi destinasi sesuai peminatannya. Selain berupa peta, tim pengabdian juga memberikan rancangan pamflet serta papan informasi, yang mana hal ini dapat memudahkan pengunjung yang datang. Sedangkan untuk menjangkau market yang lebih luas, tim juga mengusulkan platform daring sebagai etalase wisata melalui media sosial populer.

Pada gambar di bawah ini tersaji draft peta titik wisata yang ada di Boro, Banjarasri, dengan kategorisasi spesifik. Peta ditampilkan dengan grafis yang sederhana dan mudah dipahami oleh masyarakat umum, dengan pilihan komposisi warna yang tidak terlalu ramai. Peta ini dicetak dalam ukuran besar (A0) dan akan dipasang pada papan informasi yang juga didesain khusus oleh tim pengabdian, dan ditempatkan di titik strategis kedatangan pengunjung. Pamflet disediakan untuk dapat diambil pengunjung sebagai panduan wisata yang ada di seluruh Boro.

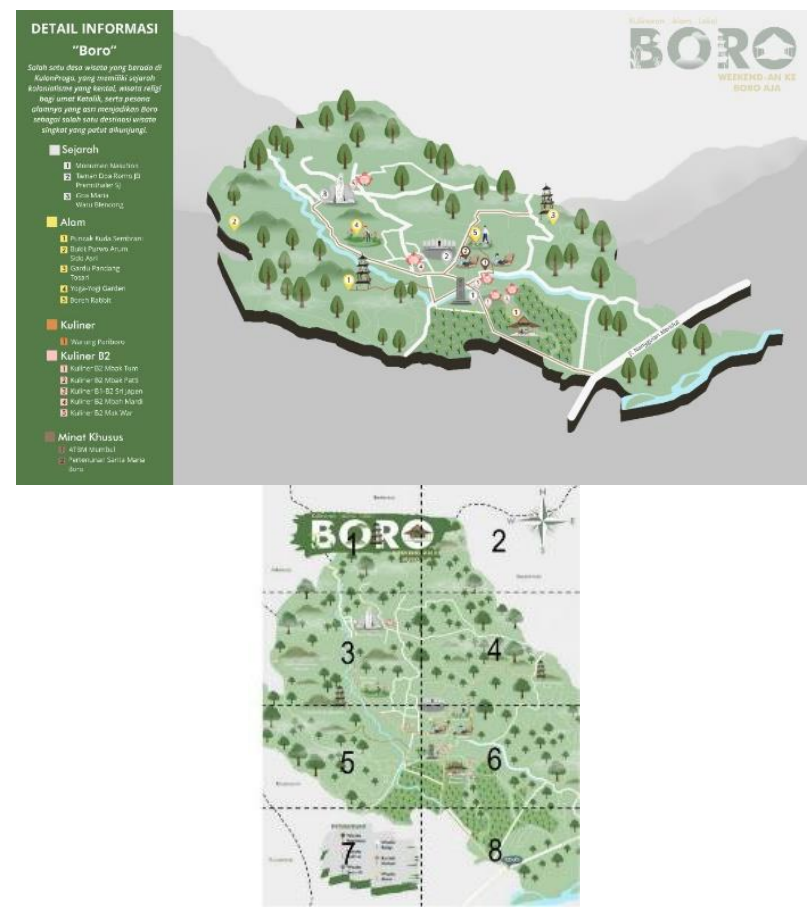

Gambar 3. Draft Peta Titik Wisata Boro dan Pamflet Saku Sumber : Tim Penulis 
Setelah pemetaan selesai, tahap lanjutan adalah pengembangan spot-spot potensi wisata tersebut, dimana dalam hal ini diperlukan partisipasi yang lebih besar dari dari lebih banyak pihak. Tim pengabdian mencoba untuk menginisiasi dengan memberikan usulan rancangan penataan salah satu spot wisata alam yaitu Trekking Puncak Kuda Sembrani, yang terletak di Bukit Menoreh. Spot potensial ini ini membutuhkan perencanaan yang matang serta konsolidasi yang kuat untuk dapat menyatukan harapan seluruh pihak terkait, terutama masyarakat setempat yang akan mengelola ke depannya. Hal ini penting, karena keberhasilan pengelolaan ekowisata tergantung pada kualitas penyedia jasa wisata (termasuk perencana, pengembang, operator, dan pengelola). Diperlukan kemitraan yang kuat antara pemerintah, industri pariwisata, masyakarat lokal, penyandang dana, Lembaga Swadaya Masyarakat, dan wisatwan untuk mencapai keberhasilan dalam penyelenggaraan ekowisata [9].

Pada gambar di bawah ini dapat dilihat jalur trekking yang dipetakan pada saat survei oleh tim pengabdian bersama dengan beberapa warga setempat, dengan menggunakan aplikasi Strava di smartphone. Trekking menanjak dari ketinggian 150 dpl menuju 300 dpl, dengan jarak berjalan sejauh kurang lebih $1 \mathrm{~km}$. Trek ini cukup bersahabat dengan kemampuan berjalan wisatawan secara umum, tidak terlalu jauh serta tidak membutuhkan persiapan khusus untuk melakukannya. Perancangan dilakukan untuk meningkatkan kualitas jalur trekking serta menambahkan amenitas pendukung bagi wisatawan, seperti toilet, tempat istirahat sementara, spot selfie, ataupun tempat penjualan air minum di sepanjang jalur menuju ke puncaknya.
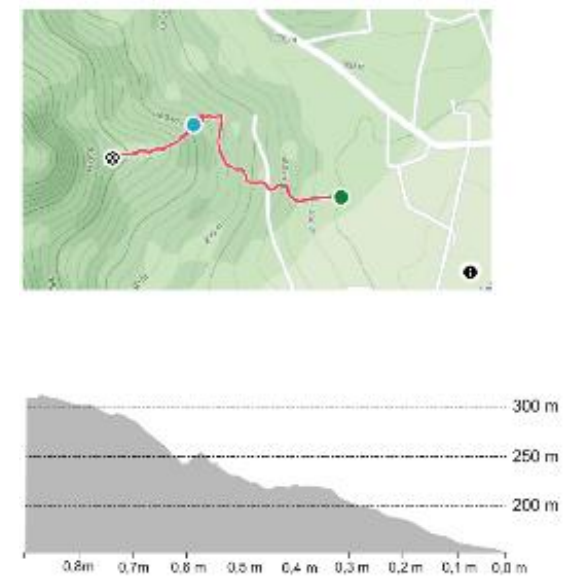

Gambar 4. Jalur Trekking Puncak Kuda Sembrani di Bukit Menoreh, Boro, Banjarasri Sumber : Tim Penulis

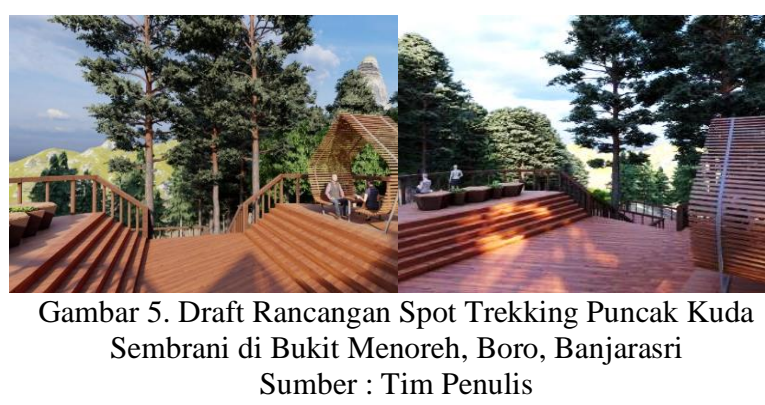

4. Tahap Sosialisasi :

Tahap ini adalah tahap akhir dari fase pendampingan pertama. Hasil dari proses konsolidasi, identifikasi, analisis yang terangkum menjadi satu gambaran besar plus satu usulan rancangan detail salah satu spot wisata potensialnya, disusun menjadi satu paparan konsep yang komperehensif.

Paparan ini disampaikan kepada warga yang lebih luas, oleh tokoh masyarakat setempat yang sedari awal memiliki semangat tinggi untuk pembangunan desa melalui ekowisata dan terlibat pada setiap prosesnya, sedangkan tim pengabdian lebih sebagai fasilitator yang mempersiapkan dan memandu prosesnya. Hal ini penting, karena dengan prinsip dari, oleh, dan untuk warga masyarakat lokal itu sendiri, maka masyakarat akan lebih berdaya, serta menumbuhkan rasa kepemilikan bersama, yang ke depannya akan memberikan dampak positif, dimana saat tiba waktunya tim pendampingan melepaskan perannya, maka masyarakat sudah mampu mengelola secara mandiri dan berkelanjutan.

Pengembangan Ekowisata di Desa Banjarasri berpotensi untuk mempengaruhi proses sosial yang terjadi di masyarakat. Perubahan tersebut terjadi karena terdapatnya kerjasama yang baik, ataupun persaingan yang akan timbul antar pelaku pariwisata. Proses sosial merupakan aspek yang dinamis dalam kehidupan bermasyarakat, dalam berbagai bentuk baik positif maupun negatif [10]. Tokoh masyarakat setempat yang bergerak sebagai pelopor memiliki pengaruh yang jauh lebih besar di masyarakat, dibandingkan dengan tim pengabdian yang sebatas sebagai pendamping. Oleh karena itu, untuk mengelola dinamika sosial yang mungkin terjadi ke depannya, maka sedari awal masyarakat sendirilah yang tampil dalam setiap prosesnya.

Dengan dimulai pendampingan ini, masyarakat telah mulai bergerak lagi untuk membangun desa secara bersama-sama, dan melalui perencanaan tata kelola yang baik, mempersiapkan atraksi, akses, dan amenitas, dan diharapkan ke depannya masyarakat Desa Banjarasri 
akan mendapatkan impact yang positif baik dari sisi ekonomi, sosial, budaya serta lingkungan.

\section{KESIMPULAN}

Pada Kegiatan Pengabdian Masyarakat di Desa Banjarasri ini, partisipasi masyarakat sangatlah penting. Masyarakat tidak sekedar menjadi obyek, namun justru menjadi subyek utama kegiatan, dimana tim pengabdian UKDW justru hanya berperan sebagai fasilitator saja.

Menggunakan metode partisipatif dalam kegiatankegiatan Bersama seperti koordinasi awal, lalu survey, serta diskusi dan workshop aktif dalam FGD, masyarakat ternyata cukup antusias. Muncul berbagai ide untuk mengembangkan spot yang ternyata potensial, misalnya wisata mina padi, wisata kelinci "Boreh", serta minat khusus tenun dan religisejarah, dll. Menjadi menarik karena informasi yang didapatkan adalah langsung berasal dari inisiatif dan impian warga akan perkembangan desanya.

Diharapkan dengan pancingan seperti ini, ke depan masyarakat Boro dapat mengembangkan lebih lanjut secara mandiri apa yang telah dimulai bersama tim pegabdian melalui kegiatan PkM UKDW di Boro Banjarasri ini. PkM lanjutan bisa dilakukan dengan Pendampingan Pengembangan Potensi lain yang sudah terpetakan namun belum tergarap.

\section{UCAPAN TERIMA KASIH}

Program kegiatan pengabdian kepada masyarakat ini dapat berjalan atas dukungan dari Lembaga Penelitian dan Pengabdian pada Masyarakat serta Fakultas Arsitektur dan Desain Universitas Kristen Duta Wacana Yogyakarta bersama dengan segenap masyarakat Boro, Desa Banjarasri, Kalibawang, Kulon Progo.

\section{DAFTAR PUSTAKA}

[1] N. E. Suriani dan M. N. Razak, "Pemetaan Potensi Ekowisata di Taman Nasional Baluran," Jurnal Masyarakat, Kebudayaan dan Politik, pp. 251-260, 2011.

[2] Y.-S. Lee, L. J. Lawton dan D. B. Weaver, "Evidence for a South Korean Model of Ecotourism," Jurnal of Travel Research, p. 520, 2012.

[3] A. Sugiama, Manajemen Aset Pariwisata: Pelayanan Berkualitas agar Wisatawan Puas dan Loyal, Bandung: Guardaya Intimatra, 2013.

[4] Dinas Pariwisata Kulon Progo, "Dinas Pariwisata Kulon Progo," Dinas Pariwisata Kulon Progo, 210 2017. [Online]. Available: https://dinpar.kulonprogokab.go.id/desa-wisata-banjarasri.html. [Diakses 102 2021].

[5] B. Sunaryo, Kebijakan Pengembangan Destinasi Pariwisata, Jogjakarta: Grava Media, 2013.
[6] Perlindungan Hutan dan Konservasi Alam, "Pedoman Analisis Daerah Operasi Obyek dan Daya Tarik Wisata Alam (ADOODTWA)," Direktorat Jenderal Perlindungan Hutan dan Konservasi Alam, Bogor, 2003.

[7] E. Laily dan E. Imro'atin, "Partisipasi Masyarakat dalam Perencanaan Pembangungan Partisipatif," Jurnal Kebijakan dan Manajemen Publik, vol. 3, no. 2, pp. 186-190, 2015.

[8] Ernawati dan T. Kurniawan, "Partisipasi Publik, Konsep dan Metode," Mimbar, vol. 18, no. 1, pp. 1-30, 2002.

[9] F. Asmin, Ekowisata dan Pembangunan Berkelanjutan : Dimulai dari Konsep Sederhana, Padang: Institut Pertanian Bogor, 2017.

[10] E. Hijriati, "Pengaruh Ekowisata Berbasis Masyarakat terhadap Perubahan Kondisi Ekologi, Sosial dan Ekonomi di Kampung Batusuhunan, Sukabumi," Jurnal Sosiologi Pedesaan, ISSN : 2302 - 7517, vol. 02, no. No. 03, pp. 146-159, 2014. 